\title{
A conceptual model to understand the drivers of change in tropical wetlands: a comparative assessment in India and Brazil
}

\author{
Priyanka Sarkar $^{1,2 *}{ }^{\circledR}$, Mercy Salami ${ }^{3}$, Yvonne Githiora $^{4}$, Raísa Vieira $^{5}$, Alma Navarro ${ }^{6}$, Diana Clavijo $^{7}$ \& \\ Maíra Padgurschi ${ }^{8,9}$ [i] \\ ${ }^{1}$ Assam University, Department of Ecology and Environmental Science, 788011, Silchar, Assam, Índia. \\ ${ }^{2}$ Drexel University, Wetland Ecology Department, Patrick Center for Environmental Research, Academy of \\ Natural Sciences, 19103, Philadelphia, Pennsylvania, USA. \\ ${ }^{3}$ University of Ilorin, Faculty of Agriculture, Department of Agricultural Economics and Farm Management, \\ 1515, Illorin, Nigeria. \\ ${ }^{4}$ University of Nairobi, Institute for Climate Change and Adaptation, UoN, Nairobi, Kenya. \\ ${ }^{5}$ Instituto Internacional para Sustentabilidade, 22460-320, Rio de Janeiro, RJ, Brasil. \\ ${ }^{6}$ Centro de Investigación en Alimentación y Desarrollo, 82100, Mazatlán, Sinaloa, México. \\ ${ }^{7}$ Universidade de São Paulo, Escola de Engenharia de São Carlos, 13566-590, São Carlos, SP, Brasil. \\ ${ }^{8}$ Instituto Nacional de Pesquisas da Amazônia, 69067-375, Manaus, AM, Brasil. \\ ${ }^{9}$ Universidade Estadual de Campinas, Centro de Pesquisas Meteorológicas e Climáticas Aplicadas à \\ Agricultura, 13083-970, Campinas, SP, Brasil. \\ *Corresponding author: Priyanka Sarkar,e-mail: prianca.sarkar9@gmail.com
}

SARKAR, P., SALAMI, M., GITHIORA, Y., VIEIRA, R., NAVARRO, A., CLAVIJO, D., PADGURSCHI, M. A conceptual model to understand the drivers of change in tropical wetlands: a comparative assessment in India and Brazil. Biota Neotropica 20(suppl. 1): e20190913. https://doi.org/10.1590/1676-0611-BN-2019-0913

\begin{abstract}
Tropical wetlands are amongst the most biodiverse ecosystems on Earth and have immense socioecological value. However, tropical wetlands are considered exploitable resources and continue to be drained and converted to other "productive" uses. It is therefore urgent to identify and understand the interactions between various drivers of change triggering degradation of such wetlands. In the present study, we systematically reviewed and analyzed the existing literature on wetlands in two tropical countries namely India and Brazil with special reference to inland wetlands, and proposed a conceptual model illustrating the intricate linkages of such wetlands with different drivers of change. We also developed the Nature Futures' Framework to depict the diverse values of inland wetlands contributing to human wellbeing in the two tropical countries. Findings revealed similar drivers of change triggering the degradation of Indian and Brazilian wetlands. These include changes in climate \& land use, population growth, poor land governance due to weak policies, besides other anthropogenic activities such as deforestation, and overexploitation of wetland resources. Among these, land-use change such as agriculture intensification and infrastructure development were the major direct drivers; whereas, institutional and governance factors such as the absence of concrete policy measures were the major indirect drivers threatening the inland wetlands in India and Brazil. Results also revealed some contrasting drivers of change such as illegal human settlements, and land grabbing by the brick industry for Indian wetlands; while, gold mining and intensification of bovine systems for Brazilian wetlands. Our paper also provides an insight into the status of wetland conservation in India and Brazil. We recommend the promotion of community-based conservation practices while adopting sustainable livelihood strategies by the local people for the conservation and wise use of inland wetlands in India and Brazil. The arguments raised in the paper have the potential to assist the stakeholders and/or decision-makers towards implementing sustainable management strategies for inland wetlands in the two countries, and tropical wetlands in general.
\end{abstract}

Keywords: Conceptual model; ecosystem services; sustainable management; wetland conservation; inland wetlands; nature futures'framework; nature's contribution to people. 
Sarkar, P. et al.

\title{
Un modelo conceptual para comprender los impulsores del cambio en los humedales tropicales: una evaluación comparativa en India y Brasil
}

\begin{abstract}
Resumen: Los humedales tropicales se encuentran entre los ecosistemas con mayor biodiversidad en la Tierra y tienen un inmenso valor socioecológico. Sin embargo, los humedales tropicales se consideran recursos exploTables y continúan siendo drenados y convertidos a otros usos "productivos". Por lo tanto, es urgente identificar y comprender las interacciones entre varios impulsores del cambio que desencadenan la degradación de dichos humedales. En el presente estudio, revisamos y analizamos sistemáticamente la literatura existente sobre humedales en dos países tropicales, a saber, India y Brasil, con especial referencia a los humedales continentales, y propusimos un modelo conceptual que ilustra el intrincado vínculo de dichos humedales con diferentes impulsores del cambio. También desarrollamos el Marco de Nature Futures para resaltar los diversos valores de los humedales continentales de India y Brasil que contribuyen al bienestar humano en los dos países tropicales. Los resultados revelaron impulsores similares de los cambios que desencadenan la degradación de los humedales de la India y Brasil, incluidos los cambios en el clima y el uso de la tierra, el crecimiento de la población, las políticas débiles y la mala gobernanza de la tierra, además de otras actividades antropogénicas como la deforestación y la sobreexplotación de recursos. Entre estos, el cambio en el uso de la tierra, como la intensificación de la agricultura y el desarrollo de infraestructura, fueron los principales impulsores directos, mientras que los factores institucionales y de gobernanza, como la ausencia de medidas políticas concretas, fueron el principal impulsor indirecto que amenazó los humedales continentales de India y Brasil. Los resultados también revelaron algunos factores de cambio contrastantes, como los asentamientos humanos ilegales y el acaparamiento de tierras por parte de la industria del ladrillo para los humedales indios; mientras que la extracción de oro y la intensificación de los sistemas bovinos para los humedales brasileños. Nuestro documento también proporciona una visión sobre el estado de la conservación de humedales en India y Brasil. Recomendamos la promoción de prácticas de conservación basadas en la comunidad al adoptar estrategias de medios de vida sostenibles por parte de la población local para la conservación y el uso racional de los humedales continentales en India y Brasil. Los argumentos planteados en el artículo tienen el potencial de ayudar a las partes interesadas y / o los tomadores de decisiones para implementar estrategias de gestión sostenible para los humedales continentales en los dos países, y para los humedales tropicales en general.
\end{abstract}

Palabras clave: Modelo conceptual; servicios ecosistémicos; gestión sostenible; conservación de humedales; humedales del interior; marco de futuros de la naturaleza; contribución de la naturaleza a las personas.

\section{Introduction}

Wetlands refer to the land saturated with water, either seasonally or permanently. Cowardin (1991) defined wetlands as the transitional lands between the terrestrial and aquatic systems where the water table is usually at or near the surface or the land is covered by shallow water. According to the Ramsar Convention (1971), wetlands are the "areas of marsh, fen, peatland or water, whether natural or artificial permanent or temporary, with water that is static or flowing; fresh, brackish, or salty, including areas of marine water the depth of which at low tide does not exceed six meters". Categorized as coastal (also termed as tidal, saltwater or estuarine wetlands), and inland (also termed as non-tidal, freshwater wetlands) (Barbier et al. 1997), wetlands are amongst the most productive ecosystems on Earth (Ghermandi et al. 2008). They exist in every climatic zone, from dry regions to high altitudes, from the tropics to the polar regions and include deltas, floodplains, flooded forests, lakes, mangroves, marshes, peatlands, rice-fields, rivers, and swamps (Wetlands International, https://www.wetlands.org). Covering only $7 \%$ of Earth's surface, wetlands deliver ecosystem services worth of at least US\$ 47 trillion per year, which accounts for $43 \%$ of the value of all ecosystems on Earth (Davidson et al. 2019). Thus, wetlands make a vital contribution towards the social, cultural and economic wellbeing (Emerton \& Bos 2004, Turner et al. 2008), given their intricate relationship with the socio-economic system (Figure 1). According to
Ramsar (2018), wetlands are known to significantly contribute to the Sustainable Development Goals, either directly or indirectly, and hence, conservation and wise use of wetlands are regarded as the cost-effective investments for the governments.

Tropical wetlands are considered as one of the most biodiverse ecosystems in the world (Junk 2002). In every continent, tropical wetlands significantly contribute to the regional and national economy and support a large number of local communities (Junk et al. 2002, Gopal 2013, Roggeri 2013, Junk et al. 2014). However, wetlands in the tropics are degrading at an alarming rate due to the rapid population growth and economic development during the last century, and consequently their conversion into different land-use types for the production of food and other commercial goods (Junk et al. 2002, Murdiyarso et al. 2010, Koh et al. 2011, Gopal 2013, Roggeri 2013). In addition, changes in seasonal hydrology due to extreme weather events as a result of climate change have further threatened the tropical wetlands (Junk et al. 2002, Gopal 2013, Roggeri 2013, Middleton \& Souter 2016). Moreover, weak- policy and management strategies that do not consider long-term conservation strategies comprise the most important factors affecting the natural integrity of tropical wetlands (Gopal 2013, Bassi et al. 2014). Such negative impacts are expected to become more intense in the near future despite the economically valuable ecosystem services provided by tropical wetlands (Decleer et al. 2016, Osland \& Middleton 2018). Consequently, the health and well-being 


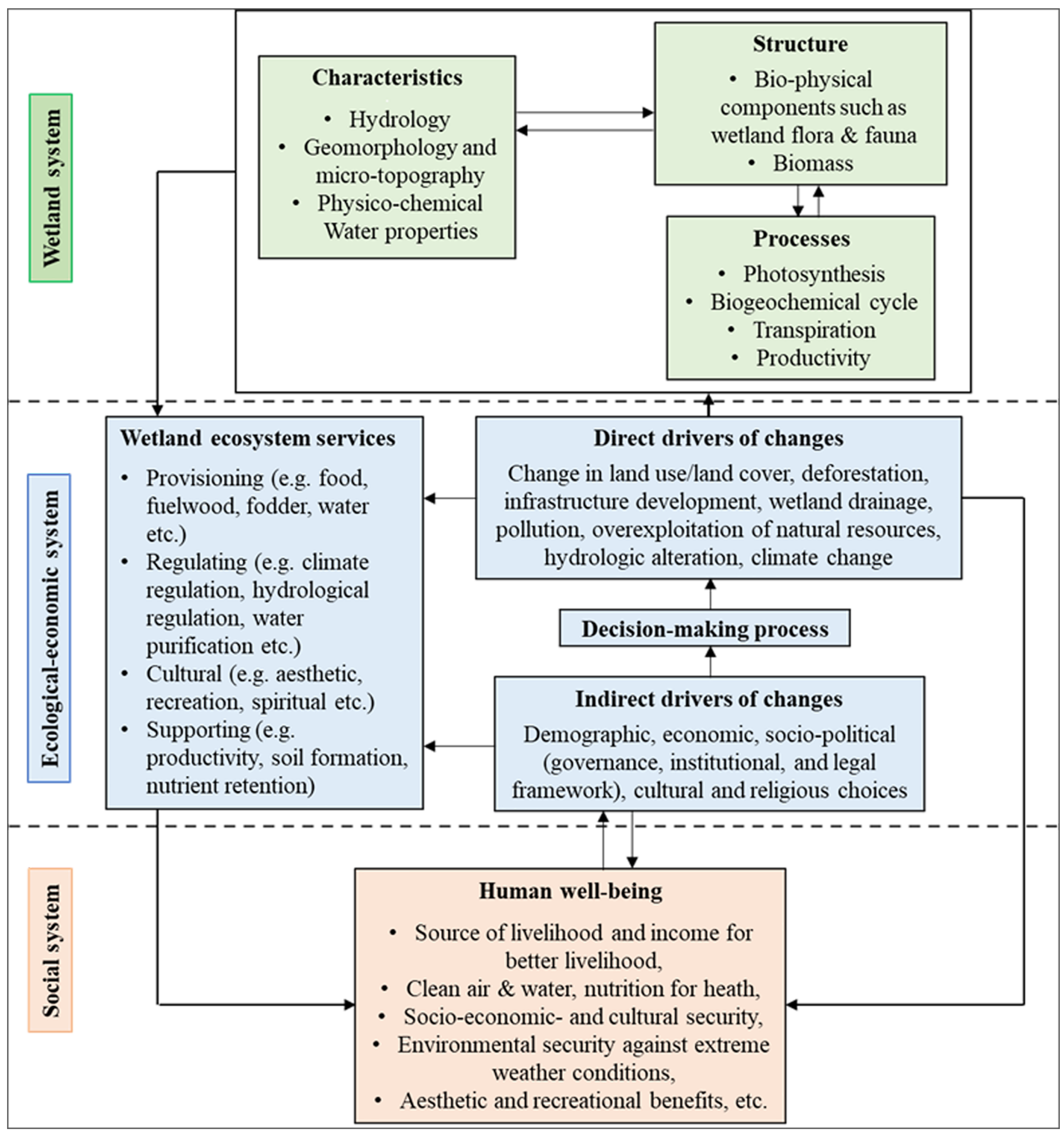

Figure 1. The linkage between wetlands with socio-economic systems and human well-being (adapted from Millennium Ecosystem Assessment 2003).

of dependent communities would be severely affected, further pushing them towards socio-economic bankruptcy (Millennium Ecosystem Assessment 2005). Literature suggests that poor understanding of the impact of developmental activities and other drivers on the ecology and functioning of wetlands is one of the potential causes for conversion and/or reclamation of tropical wetlands (Roggeri 2013).

Hence, there is an urgent need to identify and understand the interactions between various drivers of change triggering wetland degradation and maintain their ecological character for perpetual delivery of ecosystem services. In this regard, conceptual models could play a vital role in the formulation and implementation of evidence-informed policy measures towards conservation and wise use of wetlands at various spatiotemporal scales (Palmeri et al. 2000). Conceptual models are valuable communication tools that provide a simplified representation of the current knowledge of a system by portraying the complex interactions of ecosystem processes with 
the various drivers of change (Gross 2003, Imgraben et al. 2014, Wiebkin 2014). Drivers of change refer to all factors that directly or indirectly change the ecological systems, anthropogenic assets, nature's contributions to people, and good quality of life (IPBES, https:// ipbes.net/glossary/driver). Direct drivers of change (both natural and anthropogenic) such as climate change, pollution, land-use change, invasive alien species, over-exploitation of natural resources, etc., have a direct influence on biodiversity and ecosystem processes. Conversely, indirect drivers including socio-economic and demographic trends, socio-cultural factors, governance, technological innovation, etc. do not directly affect nature, rather affect the direction, level, or rate of direct drivers (Ferrier et al. 2016).

Considering the above, we systematically reviewed the existing literature on wetlands to collect information on the different drivers of change for wetlands in two tropical countries namely India and Brazil with special reference to inland wetlands. India and Brazil comprise some of the most important tropical wetlands distributed in the dry-wet climates (Osland and Middleton 2018), which sustains the livelihood of a significant portion of the human population (Wantzen et al. 2008, Junk et al. 2014, Kumar et al. 2017).

The specific objectives of the study were to (i) develop a conceptual model to identify and understand the interactions between various direct and indirect drivers triggering the degradation of inland wetlands in India and Brazil; and, (ii) develop the Nature Futures' Framework illustrating the diverse values of inland wetlands of India and Brazil contributing to human wellbeing; besides, identifying the indicators to measure and monitor changes in wetland values. The proposed conceptual model could support in understanding the intricate relationship of the various factors affecting the integrity of tropical inland wetlands. The arguments raised in the paper have the potential to assist the stakeholders and/or decision-makers towards implementing sustainable management strategies for inland wetlands in India and Brazil, and tropical wetlands in general.

\section{Materials and Methods}

\section{Study area}

The present study focused on the tropical inland wetlands in India and Brazil. Inland/non-tidal wetlands are located in floodplains along rivers and streams (riparian wetlands); isolated depressions along the margins of lakes and ponds; marshes, swamps, wet meadows and other low-lying areas where the soil surface is intercepted by groundwater or precipitation; and dominated by herbaceous plants, shrubs, and trees (US Environmental Protection Agency, https://www.epa.gov/wetlands/ what-wetland). India is endowed with 19 different types of wetlands comprising both inland (lakes/ponds, high-altitude wetlands, riverine wetlands), and coastal (lagoons, intertidal/salt marsh, mangroves, coral reefs) wetlands (Panigrahy et al. 2012). In India, wetlands cover $28,205,200$ ha $(8.99 \%)$ of the total $315,274,196$ ha area of the country (Figures 2a and 2c), 43.4\% of which is accounted for natural inland wetlands (Panigrahy et al. 2012). Whereas, Brazil harbors diverse wetlands including the 'Pantanal Matogrossense' (Mato Grosso Floodplains), river floodplains, Amazonian wetlands (igapos, igarapes, etc), and coastal ecosystems (mangroves, beaches, lagoons) (Diegues 1994). , Brazilian wetlands cover $88,113,898$ ha $(10.40 \%)$ of the total
$847,307,527$ ha area of the country (Figures $2 b$, and 2c). The Pantanal of Brazil is the largest inland wetland on Earth (Junk et al., 2014, Cunha et al. 2015), covering an area of 140,000 sq. km which accounts for $1.65 \%$ of the total geographical area of the country. In addition to the natural wetlands, man-made wetlands such as dams, reservoirs, salt pans, tanks also exist in both the countries stretching around thousands of kilometers (Diegues 1994, Panigrahy et al. 2012).

Wetlands in India provide a wide range of ecosystem services towards sustenance of local livelihood through the provision of agriculture, fishery, irrigation, jute-retting, fuelwood, raw materials for house construction and small-scale industries like pottery and handicrafts, fodder for livestock, and ecotourism (Das et al. 2000, Sarkar et al. 2019a). Palanisami et al. (2010) reported that $60 \%$ of India's tank-irrigated area is provided by wetlands in the states of Andhra Pradesh, Karnataka, and Tamil Nadu. Indian wetlands also play a significant role in carbon stocking due to their high biodiversity (Pal et al. 2017, Sarkar et al. 2019b), although agricultural activities have shown wetlands as net emitters, rather than net sinks of carbon (Kathiresan \& Thakur 2008). In addition, wetlands in India have also been shown to be important refuges for $\sim 1200$ and 1300 species of migratory birds from Europe during the winter months (Agarwall 2011). Similarly, the Pantanal ecosystem in Brazil has a great contribution towards livelihood sustenance of the local communities through the provision of various ecosystem services such as agriculture, fish, wild edible plants, ecotourism, medicinal plants, pasture for cattle grazing, etc. (Serrati 2018). In addition, Pantanal provides raw materials for house construction, making of boats, fuelwood, etc. (Chiaravalloti 2016), thus supporting the economic and cultural activities of the traditional communities (Reis et al. 2006). Pantanal also provides refuge to a wide variety of flora and fauna, including many endangered species such as jaguar (Panthera onca) and Brazilian giant otter (Pteronura brasiliensis) (Alho \& Sabino 2011). Despite the provision of various ecosystem services, both Indian and Brazilian wetlands are being lost at an alarming rate due to increasing anthropogenic pressures (Bassi et al. 2014, Junk et al. 2014). Consequently, loss of these wetlands would severely affect the health and well-being of the dependent communities (Millennium Ecosystem Assessment 2005); besides, disrupting the continuous flow of ecosystem services indispensable for sustaining the biosphere (Tolessa et al. 2017).

\section{Methods}

\section{Development of the conceptual model}

The development of the conceptual model comprised of three steps as follows:

Step 1 comprised a systematic review of existing literature on wetlands to gather information on the different drivers of change for inland wetlands in India and Brazil. We included both scientific and grey literature in the English language, published until December 2019 (with an open initial date). Since much expert knowledge is informal and undocumented (Drescher et al. 2013), inclusion of grey literature (or non-commercially published literature such as technical reports, thesis, government documents, etc.) may ensure the inclusion of comprehensive and representative sample of available research (Haddaway \& Bayliss 2015). For literature review, we used the ISI Web of Science platform using the combination of keywords: "wetland" AND "drivers"; 

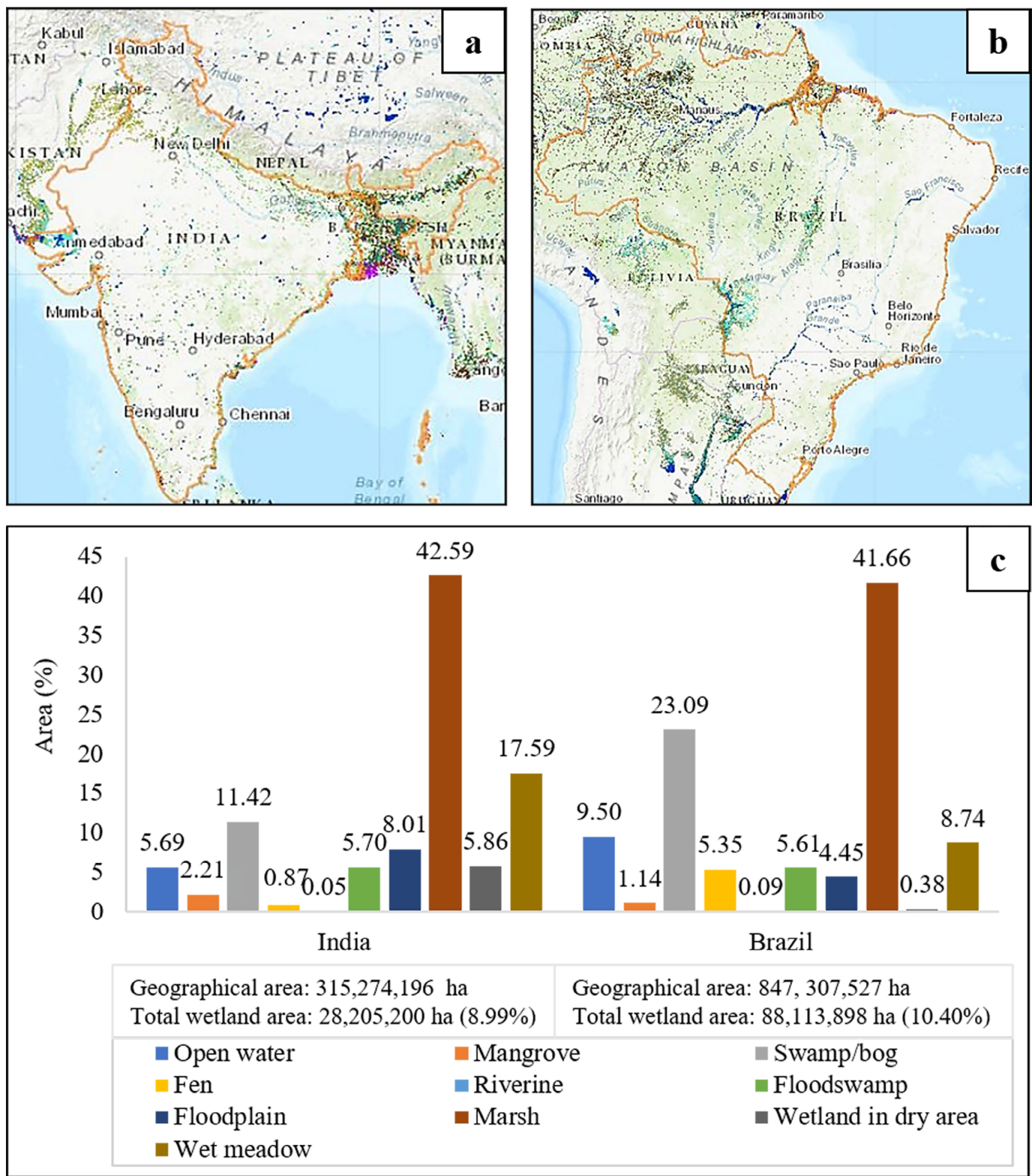

Figure 2. Distribution of wetlands in India (a), and Brazil (b), the area covered under different wetland types in India and Brazil (c). (Source: Global Wetlands, https://www.cifor.org/global-wetlands/).

"wetland" AND "conservation*"; "wetland" AND "ecosystem services*". For each combination, we added the countries such as Brazil* OR India*. The asterisk $(*)$ symbol was used with keywords that might be referred to with alternate endings. To avoid information loss, we did not include the keyword "inland" with "wetlands" because of the reason that the definition of wetlands in India and Brazil is still ongoing (Bassi et al. 2014, Gomes \& Magalhães 2017).

In step 2, all the literature returns were filtered through quickly scanning the title and abstracts of published articles. Literature describing new techniques, new species or occurrence of species, coastal 
wetlands, wetlands from other countries, etc. not directly related to our study were excluded. The filtered documents thus obtained were later analyzed in detail to extract information on the direct and indirect drivers of inland wetlands in India and Brazil.

The final step: step 3, comprised the development of the conceptual model following the 'Expert-based models' approach (Ferrier et al. 2016). An expert is someone who knows the subject of interest gained through life experience, education or training and thus possesses both scientific and non-scientific knowledge (Drescher et al. 2013). It is important to mention that the present study was developed under the close supervision of experts from Intergovernmental Science-Policy Platform on Biodiversity and Ecosystem Services (IPBES), and Brazilian Platform on Biodiversity and Ecosystem Services (BPBES) during the 'São Paulo School of Advanced Science (SPSAS) on Scenarios and Modelling on Biodiversity and Ecosystem Services to Support Human Well-Being' held in Sao Pedro, Brazil during July $1-14,2019$. During the two-week course, we were engaged in rigorous brainstorming, besides regular discussion with the experts to develop the conceptual model.

The Nature Futures' Framework was developed following Rosa et al. (2017). We also identified the indicators to measure and monitor changes in the diverse values of inland wetlands in India and Brazil. Information on indicators was obtained again through brainstorming during the process of model development at the school mentioned above.
In addition, we also reviewed the literature on indicators developed by well-known classification systems namely The Economics of Ecosystems and Biodiversity (TEEB 2010, Berghoffer and Schneider 2015), and the Common International Classification of Ecosystem Services (CICES, Haines-Young and Potschin 2013). During the entire process of model development, authors' practical experiences and in-depth understanding of the hydrology, geology, ecology of inland wetlands, their ecological and socio-cultural values, and associated socio-economic responses was constructive.

\section{Results}

\section{Drivers of change of inland wetlands in India and Brazil}

The literature search revealed 685 articles, of which, 377 articles were on inland wetlands of Brazil, and 308 articles were on inland wetlands of India (Appendix 1). Of the 377 articles, only 92 articles (24.40\%) from Brazil were relevant to our study which were later analyzed to collect required information. Whereas, only $104(33.77 \%)$ relevant articles out of 308 articles from India were analyzed to collect required information. Of the total 196 selected articles from both countries, $162(82.65 \%)$ studies addressed direct drivers of change for inland wetlands; while, some studies simultaneously studied both direct and indirect drivers. Results

Table 1. Direct and indirect drivers prevailing in inland wetlands of India and Brazil revealed through literature review.

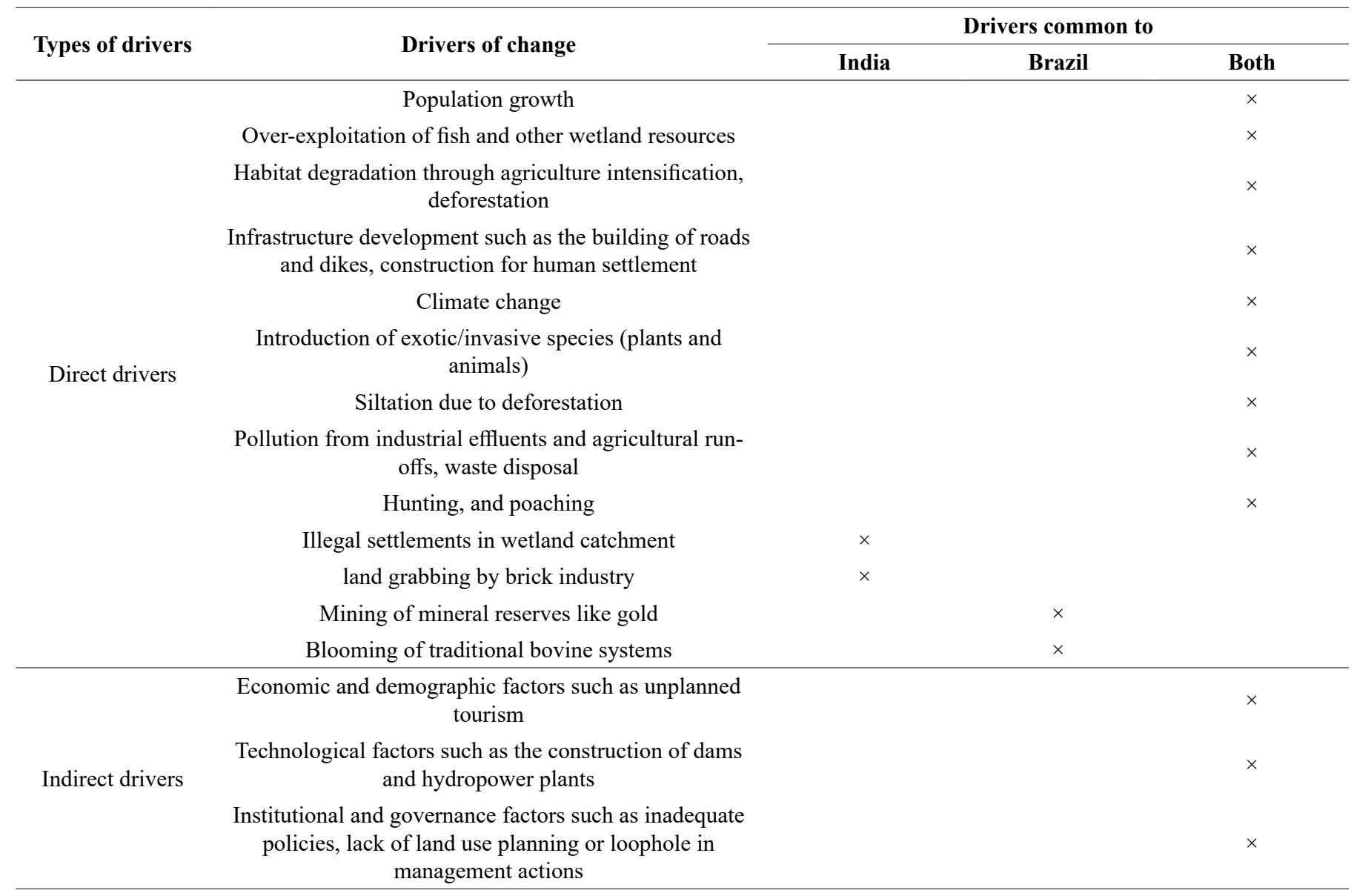

' $\times$ ' represents the presence of drivers of change in the respective countries 
revealed both similar and contrasting drivers of changes triggering the degradation of inland wetlands in India and Brazil. A list of the drivers of change affecting the inland wetlands in India and Brazil as identified from the literature survey is presented in Table 1.

Some of the major direct drivers of change common to inland wetlands in India and Brazil includes overexploitation of fish and other wetland resources like fuelwood, fodder, timber; global climate change; infrastructure development such as building of roads and dikes; agriculture intensification; habitat degradation and siltation intensified by soil erosion due to deforestation in the highlands and catchment areas; pollution from industrial effluents and agricultural run-offs, etc. (Table 1). Whereas, major indirect drivers of change common to both countries include technological factors such as the construction of dams and hydropower plants; institutional and governance factors such as loophole in management actions due to inadequate policy actions, or lack of land use planning (Table 1). Results revealed that in both countries, land-use change was the major direct driver; whereas, institutional and governance factors such as the absence of concrete policy measures, or loophole in management actions were major indirect drivers threatening the inland wetlands in India and Brazil (Table 2). Results also revealed some contrasting drivers of change for both countries, including illegal human settlements in catchment areas, and land grabbing by brick producing industry in Indian wetlands. And, mining of mineral reserves like gold, and intensification of traditional bovine systems in Brazilian wetlands (Table 1).

\section{Development of the conceptual model and Nature Futures' Framework}

Based on the results obtained above, we developed a conceptual model comprising of four components namely drivers, ecological processes, socio-economic processes, and the focal component wetland health (Figure 3). The conceptual model depicts how the identified drivers of changes, both direct and indirect, interact with one another and with ecological processes, and finally influence the focal component of the model i.e., wetland health. We identified four ecological processes such as hydrology, water quality and quantity, soil quality and quantity, and habitat availability for biodiversity that determines the health of a wetland ecosystem (Figure 3 ). In the model, we represented the ways how the drivers of change, coupled with socio-economic processes (which capture the indirect drivers of change such as policies and socio-cultural factors) impact on the ecological processes, responsible for maintaining wetland health. The relationship between the components of the model is depicted by the arrows, which shows the direction of the impact of each process. We also highlighted how the identified drivers impact on the ecological and social processes as well as on each other (Figure 3). For example, climate change affects wetland hydrology, and soil quality and quantity through changes in flooding cycles, particularly in seasonal wetlands. Climate change also acts on land use through changes in vegetation cover due to the anomalies in precipitation and temperature. While, feedback can exist between climate change and land-use change through micro-climatic changes caused by the changes in land use/land cover. Social processes such as policy and legislation also influence the drivers such as population growth and land-use change, for e.g., by restricting the types of land use that can be allowed in a particular area of wetland.

The Nature Futures' Framework developed in the present study depicts the diverse values obtained from inland wetlands of India and Brazil which contribute to human wellbeing (Figure 4). We identified a total of twenty values contributed by the inland wetlands in India and Brazil towards human well-being (Figure 4, Table 3). These values can be broadly grouped as 'Nature for Nature', 'Nature for Society', and 'Nature as Culture', all of which are interrelated. Of these identified values, a majority (15) of the values overlapped between three categories namely, Nature for Nature, Nature for society, and Nature as culture due to the inter-dependence of human and ecological processes in inland wetlands (Figure 4). The unique indicators that can be used to measure each wetland value as identified under the Nature Futures' Framework are presented in Table 3 .

\section{Discussion and Conclusions}

Wetlands are complex ecosystems characterized by an intricate relationship with the climatic, hydrological, biochemical, geomorphological, and pedological variables, necessary for maintaining its ecological character. Such complexity makes it difficult for the

Table 2. Number of studies that identified direct and indirect drivers of change in inland wetlands of India and Brazil.

\begin{tabular}{|c|c|c|c|}
\hline Driver & Type (Direct or Indirect) & Number of studies (India) & Number of studies (Brazil) \\
\hline Land-use/ land-cover change & \multirow{4}{*}{ Direct } & 41 & 39 \\
\hline Pollution & & 11 & 3 \\
\hline Natural resource use and exploitation & & 7 & 8 \\
\hline Invasive species & & 2 & 6 \\
\hline Governance and/or institutional & \multirow{5}{*}{ Indirect } & 17 & 25 \\
\hline Socio-cultural factors & & 6 & 16 \\
\hline Technological factors & & 2 & 1 \\
\hline Economic factors & & 3 & 11 \\
\hline Demographic factors & & 2 & 1 \\
\hline
\end{tabular}

*Not covered by the IPBES categories but included in our work to account for studies that identify impacts of natural drivers such as seasonal rainfal on wetlands. 


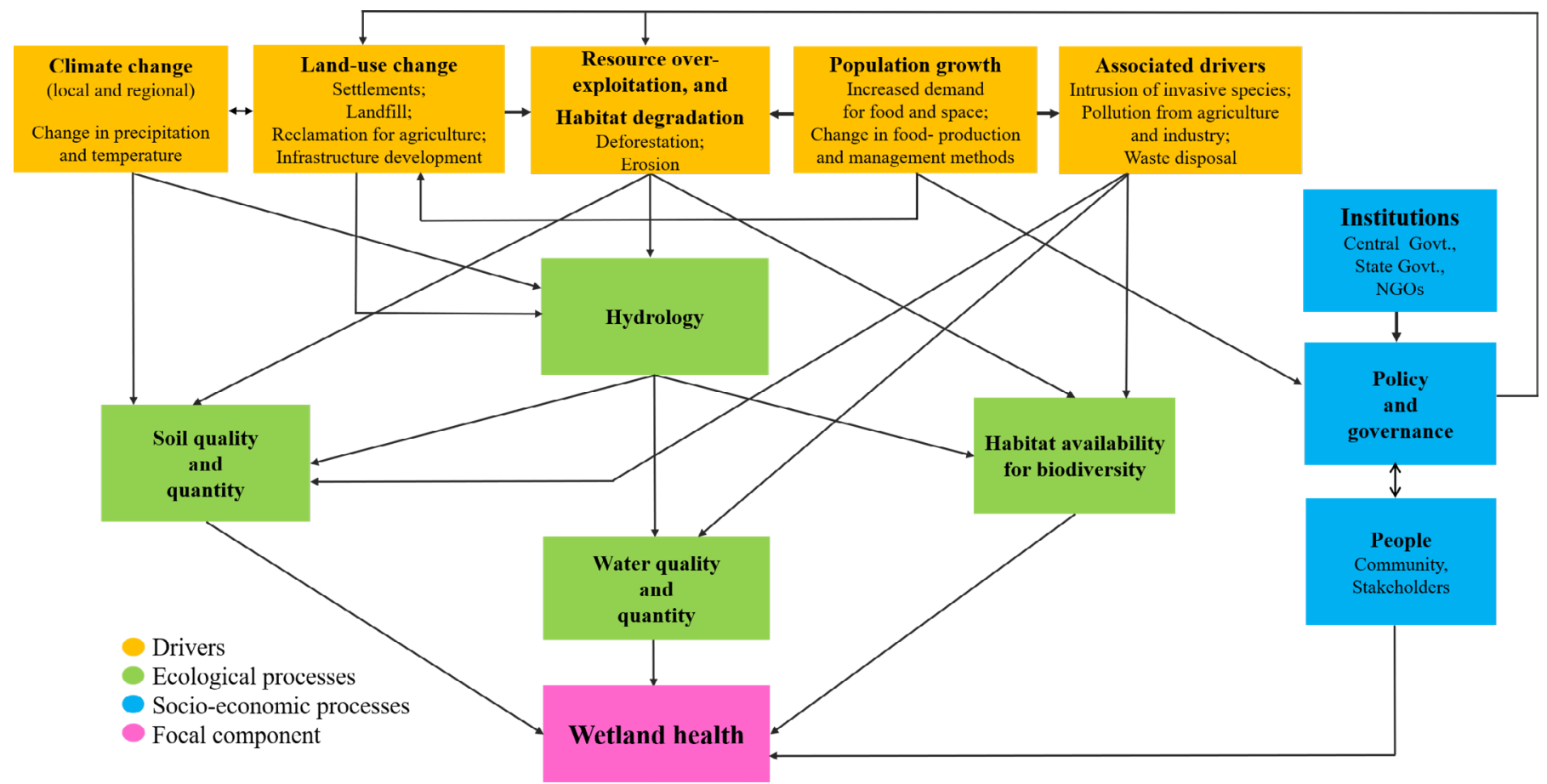

Figure 3. Conceptual model depicting the intricate relationship of wetland health with the different drivers of change. The arrows indicate the relationship and feedbacks between the different drivers, processes, and focal component of the model.

1. Breeding ground for fishes

2. Soil formation, and nutrient cycling

3. Religious and spiritual ceremonies

4. Sense of place (Identity)

5. Sacred grounds

6. Transportation

7. Brick kiln/mining

8. Food (fish, paddy, wild food)

9. Fodder

10. Fulewood

11. Research and education

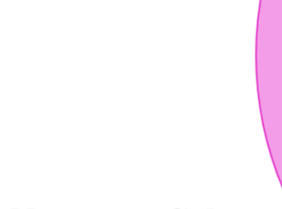

Nature as Culture

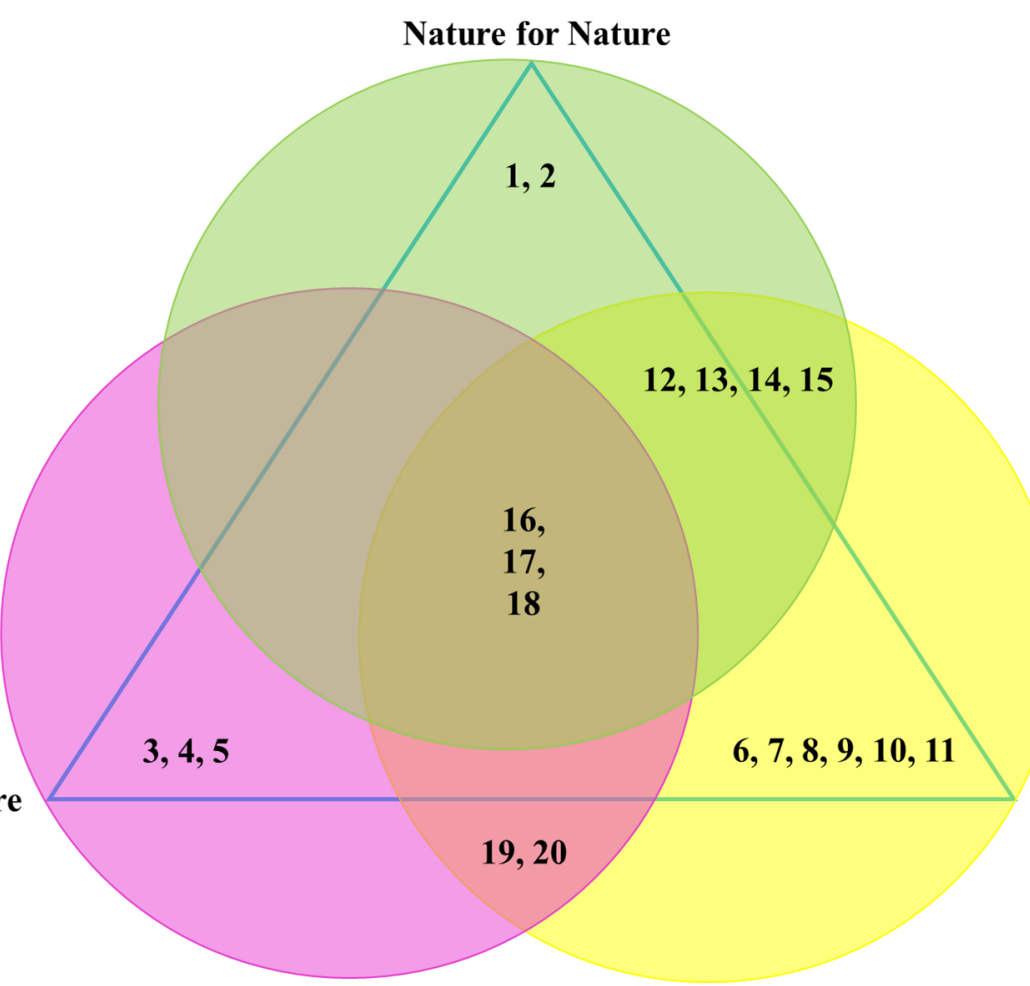

12. Habitat provision for biodiversity

13. Flood-, erosion-, climate,

and water regulation

14. Groundwater recharge

15. Genetic resources

16. Pollination

17. Monsoon

18. Recreational and aesthetic

19. Medicinal plants

20. Raw materials for pottery and handicrafts

\section{Nature for Society}

Figure 4. Nature Futures' Framework illustrating the diverse values of inland wetlands of India and Brazil contributing to human wellbeing. 
A conceptual model for tropical wetlands

Table 3. Indicators to measure the different values of inland wetlands in India and Brazil under the Nature Futures' Framework.

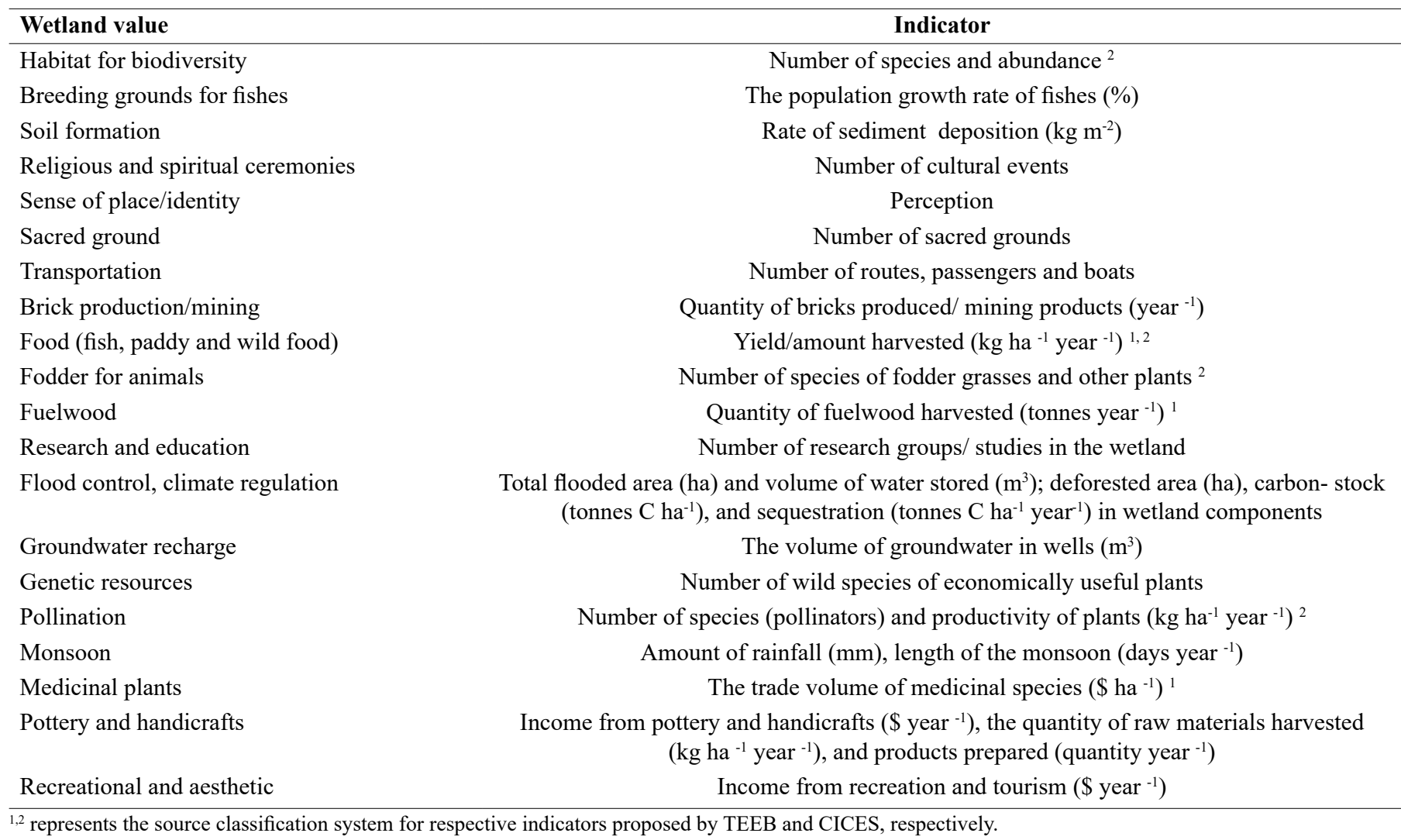

implementation of proper legislation measures for the conservation and protection of wetlands (Gomes \& Magalhães 2017). In this regard, conceptual models can portray the complex interactions of ecosystem processes with their various drivers in a simpler way, thus, assisting in the formulation of informed policy measures (Gross 2003, Imgraben et al. 2014, Wiebkin 2014, Gomes \& Magalhães 2017, Serrati 2018).

Our conceptual model for inland wetlands of India and Brazil explicitly represents the interconnected nature of the various drivers of change and ecosystem processes with wetland health and the feedbacks amongst them. As shown in the model, drivers like climate change, land-use changes, overexploitation of fish and other wetland resources, habitat degradation, population growth, and other associated drivers such as pollution from industry and agricultural run-offs, invasive species, and disposal of municipal wastes were the common drivers of change for inland wetlands both in India and Brazil (Alho \& Vieira 1997, Das et al. 2000, Prasad et al. 2002, Vila da Silva et al. 2003, Junk et al. 2005, Ministry of Environment \& Forests 2007, Central Pollution Control Board 2008, Wantzen et al. 2008, Dandekar et al. 2011, Junk et al. 2014, Mozumder et al. 2014, Roque et al. 2016, Gomes \& Magalhães 2017, Padmavathi et al. 2017, Ghosh et al. 2018, Serrati 2018, Schulz et al. 2019). Among these, the major common land-use changes in and around inland wetlands include encroachment through draining and landfill, intensive agricultural activities, infrastructure development, technological interventions such as the adoption of new and improved food production methods, construction of dams and hydropower plants, etc. Of these, agricultural intensification is a potential driver causing the shrinkage in the areal extent of inland wetlands in both the countries, thus degrading their various socio-ecological services (Mato Grosso do
Sul 1989, Bassi et al. 2014). In addition, intensification of agricultural activities in India has caused increased consumption of fertilizers from about 2.8 million tonne (1973-1974) to 28.3 million tonne (20102011) (Bassi et al. 2014), leading to eutrophication in wetlands, which further declines fish stock, and cultural values (Verhoeven et al. 2006). Similarly, intensive agricultural activities in and around the Pantanal floodplain in Brazil have severely altered the natural landscapes of the region over the last two decades (Mato Grosso Do Sul 1989). In addition, booming of the soy industry is also threatening the Pantanal ecosystem, one of the richest wildlife havens on the planet (Londoño 2017). Moreover, changing economic and political requirements, and unplanned tourism has been negatively impacting the wetland ecosystems in both the countries (Junk \& Cunha 2005, Bassi et al. 2014, Schulz et al. 2019). Furthermore, erratic rainfall patterns and elevated temperature as a result of climate change have further imposed a direct threat to the extent of tropical wetlands by altering the hydrological regimes (Gopal 2013, Schulz et al. 2019). Climate change processes are known to have intensified effects on the hydrological cycle which further intensify various climatologic events (Ching et al. 2015). Such effects of climate change are also expected to magnify the impacts of freshwater demand on freshwater ecosystems (MEA 2005), and has already been influencing the hydrological regime of inland wetlands in India and Brazil (Patel et al. 2009, Roggeri 2013). In addition, climate change is likely to impact on the soil health through physical, chemical and biological properties of soil (Patil \& Lamnganbi 2018).

In terms of the contrasting drivers of changes, illegal settlements in the catchment area, and land grabbing by brick kiln industry comprised the specific drivers for the inland wetlands in India. Urban expansion 
and population growth have increased the demand for the supply of bricks for construction leading to the proliferation of brick industries in India (Sharma et al. 2019). Such industries established near the wetland periphery uses rich topsoil from low-lying wetland areas, which along with releasing highly intensive heat destroys the soil quality and its productivity, degrading the overall quality of the environment (Gupta 2006, Noll 2015, Sharma et al. 2019). In addition, inland wetlands in India are also threatened by illegal human settlements (Mozumder et al. 2014). Whereas, excessive gold mining and intensification of traditional bovine systems (Hylander et al. 2000, Roggeri 2013, Londoño 2017, Bergier 2019, Schulz et al. 2019) were the specific drivers of change threatening the inland wetlands of Brazil. All these pressure pose a major threat to the continued existence, size, as well as wetland integrity, creating a high level of uncertainty about the future of inland wetland in India and Brazil (Ioris 2013, Bassi et al. 2014), and for the tropical wetlands in general (Gopal 2013).

With a population of 1.27 billion and a population growth rate of $1.17 \%$, India is the world's second-most populous country (FAO 2019). While, with a population of 209 million and a population growth rate of $0.73 \%$ (World Bank 2017), Brazil is the fifth most populous nation in the world. These radical population growth rates are a pointer to the pressure on the available natural resources in Brazil and India, wetlands inclusive (Guerra et al. 2020a). Increased population also comes with the challenge of higher demand for food, infrastructure and increased waste generation all of which cause both direct and indirect pressure on the inland wetlands in both the nations as represented in the conceptual model. For instance, the hydrology of the wetlands is being affected by the changes in local climate, land use as well as other human activities like landfilling, infrastructure development such as the construction of dikes \& dams, deforestation, and overexploitation. In the same vein, as shown in the model, wetland hydrology is a major determinant of the quality and quantity of soil and water as well as habitat availability for biodiversity (Guerra et al. 2020b). Our model also highlights how the soil- quality, and quality is affected by changes in local climate, land-use, and other anthropogenic activities. In addition, the conceptual model also identified the potential role of the NGOs and Institutions in maintaining the natural integrity of tropical wetlands (Gopal 2013). Therefore, there is a need to put in place the public-private partnerships at community and regional levels for conservation and sustainable management of such wetlands.

India and Brazil have been the signatories of the Ramsar Convention since 1982 and 1993 respectively, with currently 37 Ramsar sites in India covering a total area of 1,067,939 hectares, and 27 Ramsar sites in Brazil covering a total area of 26,794,455 hectares (Ramsar, https://www.ramsar.org). The Ramsar sites thus account for $3.79 \%$ and $30.41 \%$ of the overall area covered by wetlands in India and Brazil, respectively. However, there is no concrete national policy for the sustainable management and protection of wetlands in India and Brazil (Junk et al. 2014, Bassi et al. 2014, Gomes \& Magalhães 2017). In India, the judicious use of wetlands in the country still needs to gain momentum. Previously, wetlands were governed indirectly through other legal instruments including the Indian Forest Act 1927, Wildlife (Protection) Act 1972, Water (Prevention and Control of Pollution) Act 1974, Environmental (Protection) Act 1986, and Biodiversity Act 2002 of India. Provisions under these acts govern pollution of water bodies, identification of ecologically sensitive areas and conservation of aquatic biodiversity in the country which could be applied to wetlands, but without an explicit mention of the term 'wetland' (Bassi 2015). Limited understanding of wetlands as unique ecosystems and their key functions amongst the policy-makers might be the reason for the absence of proper legal instruments on wetland conservation in India (Bassi 2015). The National Environmental Policy of India (2006) recognized no national system of managing wetlands despite the international commitments made under the Ramsar Convention. Later, this recognition led to the enactment of the Wetlands (Conservation and Management) Rules, 2010. The rules vest the governance of wetlands under the Central Wetlands Regulatory Authority, and places restrictions on activities such as land reclamation within the wetland. However, the rules have been criticized as being restrictive on the types of wetlands that are regulated, restricting them to several categories. This include the Ramsar sites, UNESCO world heritage sites, wetlands in ecologically important areas, high altitude wetlands of an area of 5 ha or more, and low altitude wetlands of an area of 500 ha or more (Bassi 2015). Consequently, a large number of smaller wetlands, particularly the ones at low altitudes are overlooked and/or ignored, making them vulnerable to the impacts of drivers such as reclamation and land-filling (Dandekar et al. 2011). For instance, India has 757.06 thousand wetlands (Space Applications Centre 2011); however, only 37 of these have been identified as Ramsar sites as of the beginning of 2020. And, only 115 wetlands have garnered attention under the wetland conservation programs like National Wetland Conservation Program so far (Ministry of Environment, Forest and Climate Change, Govt. of India, http://www.moef.nic.in). While the remaining ones are highly neglected due to limited financial and technical support provided from central government (Bassi et al. 2014). Similarly, there is little progress to advance studies on Brazilian wetlands which led to marginalization in the conceptual and legal protection aspects for the wetlands. Although Brazil is endowed with several large wetlands, e.g., the floodplains of the Amazon River and several of its tributaries, Paraná and Paraguay Rivers, Pantanal Matogrossense; wetlands in Brazil are rarely mentioned in federal legislation, state constitutions, or environmental legislation (Junk et al. 2014). Literature revealed that the term 'wetland' is only used in the Native Vegetation Protection Law (Grasel et al. 2019), and most of the wetland terms in Brazil only had a regional application with weak conceptualization (Maltchik et al. 2018). Although $\sim 11 \%$ of Brazilian territory is covered by wetlands (Global wetlands, https:// www.cifor.org/global-wetlands/), wetland inventories in Brazil are still incomplete (Junk et al. 2014). Discussion on the Brazilian Forest Code suggests very little protection for the country's wetlands (Piedade et al. 2012), and the governmental policy instruments focus more on enforcing the existing environmental legislation, rather than forming a new policy instrument specifically for the wetlands (Junk et al. 2014). The 1988 Brazilian constitution only distinguished the Pantanal as a National Heritage site (Junk et al. 2014), and so far, only 27 wetlands as mentioned before are protected under the Ramsar Convention. Thus, the status of wetland conservation is very much similar between India and Brazil, revealing inappropriate policy measures and the absence of concrete governing policies specifically dedicated to the conservation of wetlands in both the countries.

Considering the above, our study, therefore recommends that allinclusive policies routed from the local communities whose livelihood depends on these wetlands be put in place. We argue that adoption 
of initiatives to change the attitudes of local people as well as the government authorities is vital towards conservation of wetlands because, the wetland-dependent communities and local stakeholders could play an instrumental role in better implementation of government policies, and might act as effective care-takers of wetlands (IUCN, https://www.iucn.org/content/working-wetlands-landowners-and-localstakeholders-life-return-rural-wetlands). There are many success stories on the proper management of wetland resources through community engagement (AWS 2001). For instance, wetlands have been effectively managed by the local people in Nepal (Shrestha 2011). While, the Life+ Return of Rural Wetlands project aiming at the restoration, management, and establishment of wetland habitats in Finland, works on a local level by encouraging and involving the local communities and stakeholders. By 2016, the project has already delivered meaningful outcomes in terms of supporting wetland biodiversity on a landscape level, thereby safeguarding the wetland habitats and the associated services. Hence, if informed properly, the local people could play an effective role in implementing concrete actions and positive changes in formulating long term policy and management practices; thus, yielding best conservation results (Kibwage et al. 2008). Moreover, we also recommend the adoption of some policy measures to create zonation within the wetland ecosystems and its catchment areas. Furthermore, conservation policies should also include (i) controlled mesh size for fishing activities (ICES 2004), (ii) regulation of fishing activities during the breeding seasons (Sadovy and Domeier 2005), (iii) restriction of brick kilns/mining activities in the core zone of wetlands, (iv) regulation of infrastructural development along the wetland catchments (Bassi et al. 2014), (v) mass awareness on wetland conservation (Paul et al. 2011, Lamsal et al. 2015), (vi) training in wetland science and management (Gopal 2013), (vii) stakeholder engagement at the local level to develop appropriate policy measures for wetland management (Kibwage et al. 2008, Lamsal et al. 2015). Such practices could restrict the destructive anthropogenic practices within the wetland core zone thus, maintaining the natural integrity of wetlands to underpin the continuous delivery of ecosystem services. Consequently, these policies will ensure protection of the diverse wetland values identified under the Natures Futures' Framework by safeguarding Nature for Nature (natural biological processes and habitats), Nature for Society (wetland resources such as food, fodder, and fuelwood), and ultimately delivering Nature as Culture services (conserving cultural practices, sacred grounds and a sense of identity for the local people). Further studies could focus on developing different scenarios to explore the effectiveness of the different policy recommendations and project their impacts on the indicators under the Nature Futures' Framework identified in the present study. While developing the conceptual model and potential policies for improved wetland conservation, integration of perspective of the local stakeholders in important, and should be discussed with the local people who directly interact with these ecosystems, which is a limitation of the present study.

Studies also suggest the promotion of sustainable livelihood options as a vital way to check further degradation of wetlands due to overexploitation (Lamsal et al. 2015). In this regard, the promotion of alternate livelihoods such as (i) ecotourism, (ii) entrepreneurial activities such as preparing handicraft items using aquatic macrophytes and other wetland resources could ensure livelihood security of the dependent communities (Lamsal et al. 2015). Although tourism has great potential for regional socio-economic development, a healthy and clean wetland is important to attract tourists (TEEB, http:// www.teebweb.org/wetlands-as-a-sustainable-tourism-destination/).

Therefore, it is important to preserve or restore the ecological integrity of wetlands and maintain the aesthetic beauty of the same. With this in mind, tourism activities in wetlands must include adoption of sound planning and management practices, for e.g., limiting the number of visitors based on the seasons, zoning of wetland areas to restrict the access and transportation of the tourists to core zone/sensitive areas, and restriction on any tourism-related constructions within the core zone (TEEB, http://www.teebweb.org/wetlands-as-a-sustainable-tourismdestination/). However, the lack of skills and financial support could be an obstacle to adopting alternative livelihood options by the local communities. In this regard, proper training and financial incentives at the initial stage, and creation of markets for the handicraft products by the local agencies would facilitate the local people in adopting alternate livelihood options (Lamsal et al. 2015).

Tropical wetlands are continuing to be regarded as resources that can be exploited, at least at a local level (Gopal 2013). Although a few tropical wetlands have received international recognition under the Ramsar Convention, national policies aiming at wetland conservation are either non-existent or very weak in both India and Brazil. Our study revealed massive anthropogenic interventions such as encroachment, changes in land use, habitat degradation, agricultural intensification, hydrological alterations through channelization \& construction of dams, dumping of industrial-, and municipal wastes, and agriculture and urban runoffs have serious impacts on inland wetlands in India and Brazil. Such anthropogenic interventions are common to other tropical wetlands as well, especially in the developing countries. Although both India and Brazil harbor a diverse wetland ecosystem, there is no policy instruments that explicitly defines the term 'wetland'. Wetlands are being given very little protection under the existing environmental legislations, with no implementation of new policies focusing solely on wetlands. However, considering the inter-dependence of human and wetland ecosystems as identified by the Nature Futures' Framework in the present study, it is indispensable to maintain the hydrological regimes and natural integrity of tropical wetlands to support human well-being and the overall biosphere. In this regard, our proposed conceptual model could help in understanding the intricate association of various drivers of change on the ecological processes and overall wetland-health; thus, assisting in the implementation of appropriate management actions at the local or regional level for inland wetlands in the two countries, and tropical wetlands in general.

\section{Acknowledgements}

The authors sincerely acknowledge the organizers of the school'São Paulo School of Advanced Science on Scenarios and Modelling on Biodiversity and Ecosystem Services to Support Human Well-Being' held in São Pedro, Brazil, for providing with the platform and financial support to develop and publish the study. The authors would also like to thank the experts of the school for their valuable guidance while developing the conceptual frameworks, and the anonymous reviewer for providing with insightful comments and suggestions. 


\section{Author Contributions}

Priyanka Sarkar: has substantial contribution in the concept and design of the study, manuscript preparation, critical revision and addition of intellectual content of the manuscript.

Mercy Salami: has substantial contribution in the concept and design of the study, manuscript preparation, critical revision and addition of intellectual content of the manuscript.

Yvonne Githiora: has substantial contribution in the concept and design of the study, manuscript preparation, critical revision and addition of intellectual content of the manuscript.

Raísa Vieira: has substantial contribution in the concept and design

of the study, critical revision,

and adding intellectual content to the manuscript.

Alma Navarro: has substantial contribution in the concept and design of the study, and

analysis of literature.

Diana Clavijo: has substantial contribution in the concept and design of the study.

Maíra Padgurschi: has substantial contribution in the concept and design of the study, manuscript preparation, critical revision and addition of intellectual content of the manuscript.

\section{Conflicts of Interest}

The authors declare that they have no conflict of interest related to the publication of this manuscript.

\section{References}

AGARWAL, M. 2011. Migratory birds in India: migratory birds dwindling. Nature December. Available at: http://newglobalindian.com/articles-andviews/nature/2033 (last accessed 20/10/2019).

ALHO, C. \& SABINO, J. 2011. A conservation agenda for the Pantanal's biodiversity. Braz. J. Biol. 71(1):327-335.

ALHO, C.J.R. \& Vieira L.M. 1997. Fish and wildlife resources in the Pantanal wetlands of Brazil and potential disturbances from the release of environmental contaminants. Environ. Toxicol. Chem. 16(1):71-74.

AWS [Asian wetland symposium]. 2001. The Penang statement on regional cooperation through partnership for wise use of wetlands, Asian wetland symposium, 27-30 August, 2001, Ramsar Center, Japan.

BASSI, N. 2015. Are wetland management strategies in India on the right trajectory? Global Water Forum. Available at https://globalwaterforum. org/2015/04/06/are-wetland-management-strategies-in-india-on-the-righttrajectory/ (last accessed 3 March 2020).

BASSI, N., KUMAR, M.D., SHARMA, A. \& PARDHA-SARADHI, P. 2014. Status of wetlands in India: A review of extent, ecosystem benefits, threats and management strategies. J. Hydrol. Reg. Stud. 2:1-19.

BARBIER, E., ACREMAN, M. \& KNOWLER, D. 1997. Economic Valuation of Wetlands: A Guide for Policy Makers and Planners. Ramsar Convention Bureau.

BERGHOFFER, A. \& SCHEIDER, A. 2015. Indicators for Managing Ecosystem Services - Options \& Examples. ValuES Project Report. Helmholtz Zentrum für Umweltforschung (UFZ) GmbH, Leipzig, and Deutsche Gesellschaft für Internationale Zusammenarbeit (GIZ) GmbH, Eschborn. Germany.

BERGIER, I., SILVA, A.P.S., DE ABREU, U.G.P., DE OLIVEIRA, L.O.F., \& BORGES-SILVA, J.C. 2019. Could bovine livestock intensification in Pantanal be neutral regarding enteric methane emissions?. Sci. Total Environ. 655(3):463-472.

CENTRAL POLLUTION CONTROL BOARD (CPCB). 2008. Status of Water Quality in India 2007. Central Pollution Control Board, Ministry of Environment and Forests, Government of India, New Delhi.
CHIARAVALLOTI, R. 2016. Local communities and conservation in the Pantanal wetland, Brazil. Doctoral dissertation, University College London, UK.

CHING, Y.C., LEE, Y.H., TORIMAN, M.E., ABDULLAH, M. \& YATIM, B.B. 2015. Effect of the big flood events on the water quality of the Muar River, Malaysia. Sustain. Water Resour. Manag. 1(2):97-110.

COWARDIN, L.M. 1979. Classification of wetlands and deepwater habitats of the United States. Fish and Wildlife Service, US Department of the Interior, USA.

DANDEKAR, P., BHATTACHARYA, S. \& THAKKAR, H. 2011. Wetland (Conservation and Management) Rules 2010, welcome, but a lost opportunity: this cannot help protect the wetlands, Sir. New Delhi: South Asia Network on Dams, Rivers \& People.

DAS, T.K., MOITRA, B., RAICHAUDURI, B. \& JASH, T. 2000. Degradation of Water Bodies and Wetlands in West Bengal: Interaction with Economic Development Theme: Wetlands and Biodiversity EERC Working Paper Series: WB-3.

DAVIDSON, N.C., VAN DAM, A.A., FINLAYSON, C.M. \& MCINNES, R.J. 2019. Worth of wetlands: revised global monetary values of coastal and inland wetland ecosystem services. Mar. Freshwater Res. 70(8):1189-1194.

DEClEER, K., WOUTERS, J., JACOBS, S., STAES, J., SPANHOVE, T., MEIRE, P. \& VAN DIGGELEN, R. 2016. Mapping wetland loss and restoration potential in Flanders (Belgium) an ecosystem service perspective. Ecol. Soc. 21(4).

DIEGUES, A.C.S.A. 1994. An inventory of Brazilian wetlands. IUCN protected areas program series, Gland, Switzerland.

DRESCHER, M., PERERA, A.H., JOHNSON, C.J., BUSE, L.J., DREW, C.A. \& BURGMAN, M.A. 2013. Toward rigorous use of expert knowledge in ecological research. Ecosphere 4(7):1-26.

EMERTON, L. \& BOS, E. 2004. Value: Counting ecosystems as water infrastructure. IUCN.

FAO. 2019. India at a glance. Available at http://www.fao.org/india/fao-in-india/ india-at-a-glance/en/ (last accessed 26/10/2019).

FERRIER, S., NINAN, K.N., LEADLEY, P., ALKEMADE, R., ACOSTA, L.A., AKÇAKAYA, H.R., ... \& WINTLE, B. A. 2016. IPBES: The methodological assessment report on scenarios and models of biodiversity and ecosystem services. Secretariat of the Intergovernmental Science-Policy Platform on Biodiversity and Ecosystem Services, Bonn, Germany.

GHERMANDI, A., VAN DEN BERGH, J.C., BRANDER, L.M., DE GROOT, H.L. \& NUNES, P.A. 2008. The economic value of wetland conservation and creation: A meta-analysis. Nota di Lavoro, No. 79.2008, Fondazione Eni Enrico Mattei (FEEM), Milano, Italy.

GHOSH, S., DINDA, S., CHATTERJEE, N. D. \& DAS, K. 2018. Analyzing risk factors for shrinkage and transformation of East Kolkata Wetland, India. Spat. Inf. Res. 26(6):661-677.

GOMES, C.S. \& MAGALHÃES Jr. A.P. 2017. Conceptual framework on wetlands in Brazil: challenges and expert opinions. Bol. Goia. Geogr. 37(3):485-505.

GOPAL, B. 2013. Future of wetlands in tropical and subtropical Asia, especially in the face of climate change. Aquat. Sci. 75(1):39-61.

GRASEL, D., FEARNSIDE, P.M., ROVAI, A.S., VITULE, J.R.S., RODRIGUES, R.R., MORMUL, R.P., ... \& JARENKOW, J.A. 2019. Brazil's Native Vegetation Protection Law Jeopardizes Wetland Conservation: A Comment on Maltchik et al. Environ. Conserv. 46(2):121-123.

GROSS, J.E. 2003. Developing conceptual models for monitoring programs. Discussion paper available at https://pdfs.semanticscholar.org/7796/115ca3 1774a9ef190459710bdc7f6172bcfe.pdf (last accessed 19/01/2020).

GUERRA, A., DE OLIVEIRA ROQUE, F., GARCIA, L.C., OCHAOQUINTERO, J.M.O., DE OLIVEIRA, P.T.S., GUARIENTO, R.D. \& ROSA, I.M. 2020a. Drivers and projections of vegetation loss in the Pantanal and surrounding ecosystems. Land Use Policy 91:104388.

GUERRA, A., DE OLIVEIRA, P.T.S., DE OLIVEIRA ROQUE, F., ROSA, I.M., OCHOA-QUINTERO, J.M., GUARIENTO, R.D., COLMAN, C.B., DIB, V., MAIOLI, V., STRASSBURG, B. \& GARCIA, L.C. 2020b. The importance of Legal Reserves for protecting the Pantanal biome and preventing agricultural losses. J. Environ. Manage. 260:110128. 
GUPTA, A. 2006. Water availability, poverty and socio-economic crisis in the floodplains of Barak Valley, Assam, Northeast India. Available at: a. https:// www.mpl.ird.fr/UR044/projets/Textes/Gupta.doc (last accessed 15/01/2020)

HADDAWAY, N.R. \& BAYLISS, H.R. 2015. Shades of grey: two forms of grey literature important for reviews in conservation. Biol. Conserv. 191(11):827-829.

HAINES-YOUNG, R. and POTSCHIN, M. 2013. Common International Classification of Ecosystem Services (CICES): Consultation on Version 4, August-December 2012. EEA Framework Contract No EEA/IEA/09/003.

HYLANDER, L.D., PINTO, F.N., GUIMARAES, J.R., MEILI, M., OLIVEIRA, L.J. \& E SILVA, E.D.C. 2000. Fish mercury concentration in the Alto Pantanal, Brazil: influence of season and water parameters. Sci. Total Environ. 261(1-3):9-20.

ICES. 2004. Mesh Size Measurement Revisited. ICES Cooperative Research Report, No. 266:56.

IMGRABEN, S., AURICHT, C., BASKERVILLE, L. \& WALKER, K. 2014 Development of conceptual models for major social and ecological systems in the South East NRM Region. Report prepared for SE NRM Board by Auricht Projects, Brighton, South Australia.

IORIS, A.A.R. 2013. Rethinking Brazil's Pantanal Wetland: Beyond Narrow Development and Conservation Debates. J. Environ. Dev 22(3):239-260.

.JUNK, W.J., PIEDADE, M.T.F., LOURIVAL, R., WITTMANN, F., KANDUS, P., LACERDA, L. D., ... \& SCHÖNGART, J. 2014. Brazilian wetlands: their definition, delineation, and classification for research, sustainable management, and protection. Aquat. Conserv. 24(1):5-22.

JUNK, W.J., NUNES DA CUNHA, C., WANTZEN, K.M., PETERMANN, P., STRÜSSMANN, C., MARQUES, M.I. \& ADIS, J. 2005. Biodiversity and its conservation in the Pantanal of Mato Grosso, Brazil. Aquat. Sci. 68(3):278-309.

JUNK, WJ. 2002. Long-term environmental trends and the future of tropical wetlands. Environ. Conserv. 29(4): 414-435.

JUNK, W.J. \& DE CUNHA, C.N. 2005. Pantanal: a large South American wetland at a crossroads. Ecol. Engg, 24(4):391-401.

KATHIRESAN, K. \& THAKUR, S. 2008. Mangroves for the Future: National Strategy and Action Plan, India. Ministry of Environment and Forests, New Delhi [Revised Draft].

KOH, L.P., MIETTINEN, J., LIEW, S.C. \& GHAZOUL, J. 2011. Remotely sensed evidence of tropical peatland conversion to oil palm. Proc. Natl. Acad. Sci. 108(12):5127-5132.

KIBWAGE, J.K., ONYANGO P.O. \& BAKAMWESIGA, H. 2008. Loca institutions for sustaining wetland resources and community livelihoods in the Lake Victoria basin. Afr. J. Environ. Sci. Technol. 2(5):097-106.

KUMAR, R., BHATT, J. R. \& GOEL, S. 2017. Natural Capital of Wetlands. Wetlands International South Asia, New Delhi, India.

LAMSAL, P., PANT, K.P., KUMAR, L. \& ATREYA, K. 2015. Sustainable livelihoods through conservation of wetland resources: a case of economic benefits from Ghodaghodi Lake, Western Nepal. Ecol. Soc. 20(1):10.

LONDOÑO, E. 2017. Brazil Wavers on Environment, and Wetlands Start to Wither. the New York edition, Section A, Page 8. https://www.nytimes com/2017/12/23/world/americas/brazil-pantanal-wetlands-michel-temer. html (last accessed 22/01/2020).

MALTCHIK, L., CALEFFI, V., STENERT, C., BATZER, D.P., PIEDADE, M.T.F. \& JUNK, W.J. 2018. Legislation for wetland conservation in Brazil: Are existing terms and definitions sufficient?. Environ. Conserv. 45(3):301-305

MATO GROSSO DO SUL. 1989. Macrozoneamento geoambiental do Estado de Mato Grosso do Sul. Campo Grande, MS: Secretaria de Planejamento e Obras de Mato Grosso do Sul - SEPLAN.

MIDDLETON, B.A. \& Souter, N.J. 2016. Functional integrity of freshwater forested wetlands, hydrologic alteration, and climate change. Ecosys. Health Sustainab 2(1):e01200.

MILLENNIUM ECOSYSTEM ASSESSMENT (MEA). 2005. Ecosystems and Human Wellbeing: Wetlands and Water Synthesis. World Resources Institute. Washington D.C.
MINISTRY OF ENVIRONMENT AND FORESTS. 2007. Conservation of wetlands in India: A profile (approach and guidelines). New Delhi: MoEF, Government of India.

MOZUMDER, C., TRIPATHI, N. K. \& TIPDECHO, T. 2014. Ecosystem evaluation (1989-2012) of Ramsar wetland Deepor Beel using satellitederived indices. Environ. Monit. Assess. 186(11):7909-7927.

MURDiYARSO, D., HERGOUALC'H, K. \& VERCHOT, L.V. 2010. Opportunities for reducing greenhouse gas emissions in tropical peatlands. Proc Natl Acad Sci 107(46):19655-19660.

NOLL, D. 2015. Socio-ecological Impacts of Brick Kilns in the Western Ghats: A socio-metabolic Analysis of small-scale Brick Industries in the Mumbai Metropolitan Region, Maharashtra, India. Social Ecology Working Paper 164, 1(6):4, Institute of Social Ecology, Vienna.

OSLAND, M.J. \& MIDDLETON, B.A. 2018. Tropical wetlands in the Anthropocene: The critical role of wet-dry cycles. Solutions J. 9(3).

PADMAVATHI, P, KANDRU, A., MISHRA, S., VHANALAKAR, S., VHANALAKAR, S. \& SRINU, G. (Eds) 2017. Wetlands of India: Biodiversity, Ecological Services and Strategies for Conservation.

PALANISAMI, K., MEINZEN-DICK, R. \& GIORDANO, M. 2010. Climate change and water supplies: options for sustaining tank irrigation potential in India. Econ. Polit. Wkly. 45 (26-27):183-190.

PAL, S., CHATTOPADHYAY, B., DATTA, S. \& MUKHOPADHYAY, S.K. 2017. Potential of wetland macrophytes to sequester carbon and assessment of seasonal carbon input into the East Kolkata Wetland ecosystem. Wetlands 37(3):497-512.

PALMERI, L., PERSSON, J., PIETERSE, N.M., TIMMERMANN, T., BENDORICCHIO, G., KLUGE, W. \& JØRGENSEN, S. E. 2000. Models for wetland planning, design and management. EcoSys Bd, 8:93-137.

PANIGRAHY, S., MURTHY, T.V.R., PATEL, J.G. \& SINGH, T.S. 2012. Wetlands of India: inventory and assessment at 1: 50,000 scale using geospatial techniques. Curr. Sci. 25(3):852-856.

PATIL, A. \& LAMNGANBI, M. 2018. Impact of climate change on soil health: A review. Int. J. Chem. Stud. 6(3):2399-2404.

PATEL, J.G., MURTHY, T.V.R., SINGH, T.S., \& PANIGRAHY, S. 2009. Analysis of the distribution pattern of wetlands in India in relation to climate change. In: Panigrahy, S., Shankar Ray, S., Parihar, J.S. (Eds.), Proceedings of the Workshop on Impact of Climate Change on Agriculture. Ahmedabad, India, 17-18 December. International Society for Photogrammetry and Remote Sensing, Ahmedabad, India.

PAUL, M., CHANDA, M. \& GUPTA, S.S. 2011. Strategy and scenario for wetland conservation in India. Chronicles of Young Scientists 2(2):79.

PIEDADE, M.T.F., JUNK, W.J., DE SOUSA Jr, P.T., DA CUNHA, C.N., SCHÖNGART, J., WITTMANN, F., CANDOTTI, E. \& GIRARD, P 2012. Wetlands under the Brazilian Forest Code. Forest Code and science: what our legislators still need to know. Executive summaries of scientific studies on the impacts of the Forest Code project, 9-17. Available at: http:// governancaflorestal.iieb.org.br/files/revista_codigo_florestal_e_a_ciencia. pdf\#page $=9$ (last accessed 04/03/2020).

PRASAD, S. N., RAMACHANDRA, T. V., AHALYA, N., SENGUPTA, T., KUMAR, A., TIWARI, A. K., VIJAYAN, V. S., \& VIJAYAN, L. (2002) Conservation of wetlands of India-A review. Trop. Ecol. 43(1):173-186.

RAMSAR SECRETARIAT. 2013. The List of Wetlands of International Importance. The Secretariat of the Convention on Wetlands, Gland, Switzerland.

REIS, D.A.F., DIAS RIBEIRO, E.C. \& BOURLEGAT, C.A.L. 2006. Cultura y territorialidad en la tradición del pantanal de Corumbá y Ladario en Mato Grosso do Sul (Brasil). Polis. Revista de La Universidad Bolivariana 5(14):291-310.

ROGGERI, H. 2013. Tropical freshwater wetlands: a guide to current knowledge and sustainable management (Vol. 112). Springer Netherlands.

ROQUE, F.O., OCHOA-QUINTERO, J., RIBEIRO, D.B., SUGAI, L.S. M., COSTA-PEREIRA, R., LOURIVAL, R. \& BINO, G. 2016. Upland habitat loss as a threat to Pantanal wetlands. Conserv. Biol. 30(5): 1131-1134. 
ROSA, I.M.D., PEREIRA, H.M., FERRIER, S., ALKEMADE, R., ACOSTA, L.A., AKCAKAYA, R., ... \& VAN VUUREN, D. 2017. Multiscale scenarios for nature futures. Nat. Ecol. Evol. 1 (10):1416 - 1419.

SADOVY, Y. \& DOMEIER, M. 2005. Are aggregation-fisheries sustainable? Reef fish fisheries as a case study. Coral Reefs 24(2):254-262.

SARKAR, P., DAS, T. \& MANDAL, R. 2019a. Assessing human dependency on the provisioning ecosystem services of Chatla floodplain wetland of Barak Valley, Assam, Northeast India. Ind. J. Ecol. 46 (3):516-520.

SARKAR, P., DAS, T. \& ADHIKARI, D. 2019b. Variation in species assemblages due to micro-topography and flow regime govern vegetation carbon stock in seasonal floodplain wetlands. Ecol. Process. 8:49.

SCHULZ, C., WHITNEY, B.S., ROSSETTO, O.C., NEVES, D.M., CRABB, L., DE OLIVEIRA, E.C., ... \& DA SILVA, C.A. 2019. Physical, ecological and human dimensions of environmental change in Brazil's Pantanal wetland: Synthesis and research agenda. Sci. Total Environ. 687(10):1011-1027.

SERRATI, V.B. 2018. Exploring ecosystem services provided by the Pantanal wetland, South America. A preliminary review of methods to improve the knowledge on the benefits provided by the wetlands. Wageningen University and Research, Netherlands. Available at: https://observatoriopantanal.org/ (last accessed 19/01/2020).

SHARMA, P., BARUAH, J., DEKA, D. \& KAUSHIK, P. 2019. Harnessing Wetlands for Sustainable Livelihood. Notion Press, India.

SHRESTHA, U. 2011. Community participation in wetland conservation in Nepal. J. Agricul. Environ. 12:140-147.

SPACE APPLICATIONS CENTRE (SAC), 2011. National Wetland Atlas. Indian Space Research Organisation (ISRO), Ahmedabad, India.

TEEB. 2010. The Economics of Ecosystems and Biodiversity Ecological and Economic Foundations. Edited by Pushpam Kumar. Earthscan, London and Washington.

TOLESSA, T., SENBETA, F. \& KIDANE, M. 2017. The impact of land use/land cover change on ecosystem services in the central highlands of Ethiopia. Ecosyst. Serv. 23:47-54.
TURNER, R.K. \& DAILY, G.C. 2008. The ecosystem services framework and natural capital conservation. Environ Res. Econ. 39(1): 25-35.

US ENVIRONMENTAL PROTECTION AGENCY (EPA). 2017. Why are wetlands important https://www.epa.gov/wetlands/wetlands-factsheet-series (last accessed 21/01/2020).

VERHOEVEN, J.T.A., ARHEIMER, B., YIN, C. \& HEFTING, M.M. 2006. Regional and global concerns over wetlands and water quality. Trends Ecol. Evol. 21(2):96-103.

VILA DA SILVA, J.S., ABDON, M.M., POTT, A. \& MAURO, R.A. (2003). Fragile Ecosystem: The Brazilian Pantanal Wetland. Encyclopedia of Life Support Systems. Pp 1-2. http://www.eolss.net/Eolss-sampleAllChapter.aspx

WANTZEN, K.M., DA CUNHA, C.N., JUNK, W.J., GIRARD, P., ROSSETTO, O.C., PENHA, J.M., ... \& SANTOS, S.A. 2008. Towards a sustainable management concept for ecosystem services of the Pantanal wetland. Ecohydrol 8(2-4):115-138.

WETLANDS (CONSERVATION AND MANAGEMENT) RULES. 2010. Ministry of Environment and Forests. Government of India, New Delhi, India.

WIEBKIN, A. 2014. Developing conceptual models - a guide for facilitating workshops. DEWNR Technical Note 2014/04. Government of South Australia, through Department of Water, Land and Biodiversity Conservation, Adelaide.

WORLD BANK (2017): Population of Brazil. Available at https://data. worldbank.org/country/brazil (last accessed 20/10/2019)

Received: $31 / 10 / 2019$

Revised: 06/03/2020

Accepted: 24/03/2020

Published online: 15/05/2020 